\title{
The impact of urban trees on concentrations of PAHs and other gaseous air pollutants in Yanji, northeast China
}

\section{Yli-Pelkonen, Vesa}

2018-11

Yli-Pelkonen, V , Viippola , V , Rantalainen , A-L , Zheng , J \& Setälä , H 2018 , ' The impact of urban trees on concentrations of PAHs and other gaseous air pollutants in Yanji, northeast China ' , Atmospheric Environment , vol. 192 , pp. 151-159 . https://doi.org/10.1016/j.atmosenv.2018.08.06

http://hdl.handle.net/10138/318769

https://doi.org/10.1016/j.atmosenv.2018.08.061

cc_by_nc_nd

acceptedVersion

Downloaded from Helda, University of Helsinki institutional repository.

This is an electronic reprint of the original article.

This reprint may differ from the original in pagination and typographic detail.

Please cite the original version. 
Yli-Pelkonen et al. 2018

\title{
The impact of urban trees on concentrations of PAHs and other gaseous air pollutants in Yanji, northeast China
}

\author{
Vesa Yli-Pelkonen ${ }^{1 *}$, Viljami Viippola ${ }^{2}$, Anna-Lea Rantalainen ${ }^{2}$, JunQiang Zheng ${ }^{3}$, Heikki \\ Setälä ${ }^{2}$
}

${ }^{1}$ University of Helsinki, Ecosystems and Environment Research Programme, Faculty of Biological and Environmental Sciences, P.O. Box 65, FI-00014 University of Helsinki, Finland; vesa.yli-pelkonen@ helsinki.fi; *Corresponding author.

${ }^{2}$ University of Helsinki, Ecosystems and Environment Research Programme, Faculty of Biological and Environmental Sciences, Niemenkatu 73, FI-15140, Lahti, Finland; viljami.viippola@helsinki.fi, anna-lea.rantalainen@helsinki.fi, heikki.setala@helsinki.fi

${ }^{3}$ Key Laboratory of Forest Ecology and Management, Institute of Applied Ecology, Chinese Academy of Sciences, 72 Wenhua road, Shenyang City, Liaoning Province 110016, People's Republic of China, jqzheng@iae.ac.cn

\begin{abstract}
Accepted final draft version
Reference:

Yli-Pelkonen, V., Viippola, V., Rantalainen, A-L., Zheng, JQ., Setälä, H. (2018) The impact of urban trees on concentrations of PAHs and other gaseous air pollutants in Yanji, northeast China. Atmospheric Environment 192: 151-159.

http://doi.org/10.1016/j.atmosenv.2018.08.061

\section{Disclaimer:}

The PDF document is a copy of the final version of this manuscript that was subsequently accepted by the journal for publication. The paper has been through peer review, but it has not been subject to any additional copy editing or journal-specific formatting. It thus looks different from the final published version, which may be accessed following the DOI above.
\end{abstract}




\begin{abstract}
It is generally conceived that trees can clean polluted air in urban areas sufficiently enough to be considered providers of a vital ecosystem service, although there have not been many field studies showing this in practice in the neighborhood scale. Using passive sampling methods, we investigated the effect of urban park trees on the concentrations of gaseous polycyclic aromatic hydrocarbons (PAHs), nitrogen dioxide $\left(\mathrm{NO}_{2}\right)$, ground-level ozone $\left(\mathrm{O}_{3}\right)$ and sulfur dioxide $\left(\mathrm{SO}_{2}\right)$ in early summer in the temperate zone city of Yanji, northeast China. Concentrations of total gaseous PAHs and certain PAH constituents were higher and concentrations of $\mathrm{O}_{3}$ lower in treecovered areas compared to nearby open areas, while tree cover did not affect the concentrations of $\mathrm{NO}_{2}$ and $\mathrm{SO}_{2}$. The higher PAH concentrations under tree canopies may associate with air-soil gas exchange and the trapping of polluted air under canopies. Lower $\mathrm{O}_{3}$ concentrations in treecovered areas may result from a combination of absorption of $\mathrm{O}_{3}$ by tree canopies, and lower temperatures and solar radiation under tree canopies compared to open areas.
\end{abstract}

Keywords: urban trees; air pollution; PAHs; nitrogen dioxide; ozone; passive sampling 
Yli-Pelkonen et al. 2018

\section{Introduction}

Worldwide, air pollution is one of the most severe urban environmental problems as concentrations of several air pollutants, such as polycyclic aromatic hydrocarbons (PAHs), nitrogen dioxide $\left(\mathrm{NO}_{2}\right)$ and ground-level ozone $\left(\mathrm{O}_{3}\right)$ pose a risk for human health (Duncan et al., 2016; EEA, 2016; Pfister et al., 2014). PAHs originate mainly from traffic-related combustion (Marr et al., 1999; Shen et al., 2011) and may have carcinogenic properties (IARC, 2010; Wang and Busby, 1993). While ca. 500 PAH compounds have been detected in the environment, usually only 16 of them (the so-called 16 EPA PAHs) are assessed. Of these, benzo[a]pyrene (BaP) is a well-characterized human carcinogen (IARC, 2010), but carcinogenicity of many PAH compounds is still uncertain. For instance, fluoranthene, which is currently not classified in terms of its carcinogenicity to humans, has been shown to have some carcinogenic properties (Boström et al., 2002; Busby et al., 1984; IARC, 2010). Other than BaP, there are little data or target values available on ambient PAH concentrations.

In urban areas, nitrogen oxides $\left(\mathrm{NO}_{\mathrm{x}}=\mathrm{NO}+\mathrm{NO}_{2}\right)$ derive mainly from traffic - either directly as $\mathrm{NO}_{2}$ or as $\mathrm{NO}$ which is rapidly oxidized by $\mathrm{O}_{3}$ to $\mathrm{NO}_{2}$ (Anttila et al., 2011; Atkinson, 2000). The concentration of ground-level $\mathrm{O}_{3}$ depends on both emissions of $\mathrm{NO}_{\mathrm{x}}$ and volatile organic compounds (VOCs) of both anthropogenic and biogenic origin, as $\mathrm{O}_{3}$ is formed when VOCs react with $\mathrm{NO}_{\mathrm{x}}$ under the influence of sunlight (Calfapietra et al., 2013; Chameides et al., 1988; Chameides et al., 1992; Loreto and Schnitzler, 2010). Consequently, inhabitants in urban and suburban areas can suffer from elevated levels of ozone (Uysal and Schapira, 2003). High levels of both $\mathrm{NO}_{2}$ and $\mathrm{O}_{3}$ are known to cause respiratory symptoms and diseases (Kampa and Castanas, 2008; Krämer et al., 2000; Uysal and Schapira, 2003). As with the above-mentioned 
air pollutants, $\mathrm{SO}_{2}$ also originates from combustion in industry and energy production and causes numerous negative health effects (Kampa and Castanas, 2008).

It is often thought that urban trees could purify urban air and thus provide an advantageous ecosystem service (Beckett et al., 2000; Nowak et al., 2006; Baumgardner et al., 2012; Morani et al., 2011), although air quality enhancement primarily requires cutting air pollutant emissions (Duncan et al., 2016; EEA, 2016). For instance, PAHs that exist in gaseous and particle-bound phases, can deposit on tree canopy surfaces (Simonich and Hites, 1994; Wagrowski and Hites, 1997) and consequently be accumulated in the cuticle and diffused into the leaf (Bakker et al., 2001; Jouraeva et al., 2002; Wang et al., 2008). Litterfall and rain take PAHs captured by the tree canopy eventually to the soil, or PAHs end up back into the atmosphere by re-suspension and re-volatilization (Howsam et al., 2001). According to Horstmann et al. (1997) and Matzner (1984), deposition of both gaseous and particle-bound PAHs into forest soils is far greater than deposition into soils of open, treeless areas, possibly due to capture of PAHs by the large surface area of trees and their subsequent transmission to the soil. On the other hand, $\mathrm{NO}_{2}$ (ChaparroSuarez et al., 2011; Hu et al., 2016; Rondón and Granat, 1994; Takahashi et al., 2005), $\mathrm{O}_{3}$ (Hu et al., 2016; Manes et al., 2012; Wang et al., 2012) and $\mathrm{SO}_{2}$ (Hu et al., 2016; Slovik et al., 1995) are mostly absorbed from the air through the stomata into the plant leaf interior. Tree leaves can also capture gaseous PAHs via stomata (De Nicola et al., 2017), although not so readily as the other gaseous pollutants mentioned here.

However, it remains controversial whether air pollutants removed by trees is sufficient to result in improved air quality in tree-covered urban areas (Pataki et al., 2011; Pataki et al., 2013). According to recent studies the potential of urban vegetation to reduce the levels of gaseous air pollutants seems to be affected by, for instance, climate, plant type and vegetation structure, and 
the scale (e.g. city scale or neighbourhood scale) at which the relationship between air quality and vegetation effect is explored (Fantozzi et al., 2015; Gromke and Ruck, 2009; Harris and Manning, 2010; Setälä et al., 2013; Tong et al., 2015; Viippola et al., 2016; Vos et al., 2013; YliPelkonen et al., 2017a, b, c).

We have previously quantified concentrations of gaseous PAHs in boreal and hemi-boreal urban near-road environments in southern Finland and found elevated PAH concentrations in treecovered habitats compared to adjacent open habitats in summer (Viippola et al., 2016). Furthermore, in our studies on the effect of trees on $\mathrm{NO}_{2}$ levels we observed; (i) no consistent effect in urban parks in southern Finland (Setälä et al., 2013; Yli-Pelkonen et al., 2017b) or the mid-Atlantic USA (Yli-Pelkonen et al., 2017a), and (ii) increased $\mathrm{NO}_{2}$ concentrations under trees in near-road urban and peri-urban environments compared to open environments (Viippola et al., 2018; Yli-Pelkonen et al., 2017c). We have also found lower $\mathrm{O}_{3}$ concentrations in tree-covered urban park habitats compared to similar open habitats in the mid-Atlantic USA (Yli-Pelkonen et al., 2017a), but no consistent effect by urban road-side parks in southern Finland (Yli-Pelkonen et al., 2017b). We have suggested that the lack of ventilation within tree canopies may increase concentrations of certain air pollutants in tree-covered habitats (e.g. Viippola et al., 2016; YliPelkonen et al., 2017c).

In the current study, our objective was to investigate whether our previous results on the influence of urban vegetation on air quality hold in a geographically distinct area with diverging air pollution patterns and vegetation types in the city of Yanji, northeast China. We hypothesized that, (i) regarding PAHs, $\mathrm{NO}_{2}$ and $\mathrm{SO}_{2}$, urban tree cover does not enhance urban air quality, but (ii) that tree cover results in lower $\mathrm{O}_{3}$ levels (Harris and Manning, 2010; Yli-Pelkonen et al., 2017a). Although the main focus of this study was to assess the effects of vegetation on PAH 
concentrations, we also quantified concentrations of $\mathrm{NO}_{2}, \mathrm{O}_{3}$ and $\mathrm{SO}_{2}$ in order to compare their behavior to that of PAHs, and thus provide a better mechanistic understanding of the impact of trees on divergent gaseous pollutants.

\section{Methods}

\subsection{Passive sampling}

The concentrations of gaseous PAHs, $\mathrm{NO}_{2}$, ground-level $\mathrm{O}_{3}$ and $\mathrm{SO}_{2}$ were measured applying dry deposition passive samplers. The samplers were placed either underneath tree canopies within tree-covered habitats or in nearby open habitats in the city of Yanji $\left(42^{\circ} 54^{\prime} \mathrm{N}, 129^{\circ} 30^{\prime} \mathrm{E}\right.$, ca. 400000 inhabitants), northeast China (Fig. 1). Yanji is situated in the temperate vegetation zone with mixed coniferous and deciduous broad-leaf forests, while vegetation composition in the city core does not necessarily reflect that of the surroundings.

\subsection{Sampling method and analyses of gaseous PAHs}

We sampled PAHs using passive sampling devices (PSDs) that are similar to the standardized semi-permeable membrane devices (SPMDs) described by Huckins et al. (1990). Our PSD mimics bioconcentration processes and collects bioavailable pollutants from the ambient environment. SPMDs have been applied in the sampling of PAHs in water (e.g. Wang et al., 2009) and the air (Piccardo et al., 2010; Söderström et al., 2005) and PSDs in studying gaseous PAHs in the urban air (Honkonen and Rantalainen, 2016; Viippola et al., 2016).

PSDs used here consisted of a low-density polyethylene layflat tubing (length $48 \mathrm{~cm} \times$ width 2.5 $\mathrm{cm}$ ) enclosing $0.5 \mathrm{~mL}$ of $>95 \%$ purity triolein (MP Biomedicals, Illkirch, France), with a total weight of $2.3 \mathrm{~g}$. While both ends of the tubing are sealed, it provides a $45 \mathrm{~cm}$ long lipid-filled 
part. We used only one PSD replicate per sampling point due to low variation observed between the two PSDs used per sampling point in Viippola et al. (2016). To assess possible exposure during the setup of the field experiment or error in the analysis, blank PSDs were used. Two field blank PSDs were carried along during the deployment of the samplers exposing them to ambient air at the sampling sites only while taking the other samplers from a container. After the exposure period, the PSDs were removed and stored at $-20{ }^{\circ} \mathrm{C}$ until analysis.

Preparation and analysis of the PSDs (16 EPA priority PAHs) is described in detail in Viippola et al. (2016). Mean of the recoveries of internal standards was $64 \pm 15 \%$. The limit of quantification (LOQ) varied between 0.04 and $2 \mathrm{ng} \mathrm{m}^{-3}$. We used literature-based uptake rates (Cranor et al., 2009) for each compound to determine mean concentrations of the PAHs in the air. These uptake rates give daily sampled air volume per one gram of sampler (unit $\mathrm{m}^{3} \mathrm{~g}^{-1} \mathrm{~d}^{-1}$ ). PAH concentrations in the air $\left(\mathrm{ng} \mathrm{m}^{-3}\right)$ were calculated by using the uptake rate, mass of individual PAH in a sampler (ng), mass of a sampler (g) and the exposure time (d). All reported PAH compounds found in the field blank PSDs and reagent blank samples (clean, unexposed PSDs) were close to the $\mathrm{LOQ}$, meaning that there was no contamination or error in the analysis.

\subsection{Sampling method and analyses of $\mathrm{NO}_{2}, \mathrm{O}_{3}$ and $\mathrm{SO}_{2}$}

$\mathrm{NO}_{2}$ and $\mathrm{SO}_{2}$ samplers were manufactured and analyzed by Metropolilab, Helsinki, Finland, and $\mathrm{O}_{3}$ samplers by the Swedish Environmental Research Institute IVL. All these diffusive passive samplers are developed by IVL. Gas flows into the sampler where it is collected to a filter paper impregnated with an absorbent solution. The gas is extracted from the filter to distilled water, and then the quantity of gas is determined using a spectrophotometer $\left(\mathrm{NO}_{2}, \mathrm{O}_{3}\right)$ or ion chromatography $\left(\mathrm{SO}_{2}\right.$ ) (Ayers et al., 1998; Ferm, 2001; Sjöberg et al., 2001). The results of this 
passive method of measuring $\mathrm{NO}_{2}$ are well corroborated by active and more expensive $\mathrm{NO}_{2}$ monitoring devices (Ayers et al., 1998; Ferm and Rodhe, 1997; Klingberg et al., 2017; Krupa and Legge, 2000; HSY, 2014). The accuracy of $\mathrm{O}_{3}$ and $\mathrm{SO}_{2}$ samplers has been demonstrated by Sjöberg et al. (2001), Ferm and Rodhe (1997) and Ferm and Svanberg (1998).

\subsection{Description of sampling sites}

We selected six urban parks in the city of Yanji (Fig. 1) and established one sampling site in each park. Air samplers were placed in two habitats at each site: a tree-covered habitat and a nearby open, treeless habitat. The habitats with tree cover were covered with trees as widely as possible in the vicinity of the sampling point. However, there often were some canopy gaps within a $25 \mathrm{~m}$ radius from the samplers. The open habitats were as treeless as possible around the sampling point, but there often were some scattered trees within a $25 \mathrm{~m}$ radius from the samplers. Such trees were situated at the circle's perimeter. At each site, the air samplers at open and tree-covered sampling points were set at about the same distance from the closest main road, but far $(>54 \mathrm{~m})$ from roads with large traffic volume where high emissions and strong turbulence may result in pollution patterns that are atypical to urban parks (e.g. Yli-Pelkonen et al., 2017c). At the six sites, the distance from the sampling points to the closest main road varied between 54 and $400 \mathrm{~m}$ (see Table 1 for the actual and mean distances of the open and treecovered sampling points) and the distance between open and tree-covered sampling points at each site ranged from 26 to $93 \mathrm{~m}$ (mean $=64 \mathrm{~m})$. The tree-covered habitats included coniferous or broad-leaf mature or semi-mature trees (Table 1). The ground layer vegetation in open habitats was principally lawn or grassland and the soil surface varied from entirely pervious to partly or almost entirely impervious asphalt surfaces. 

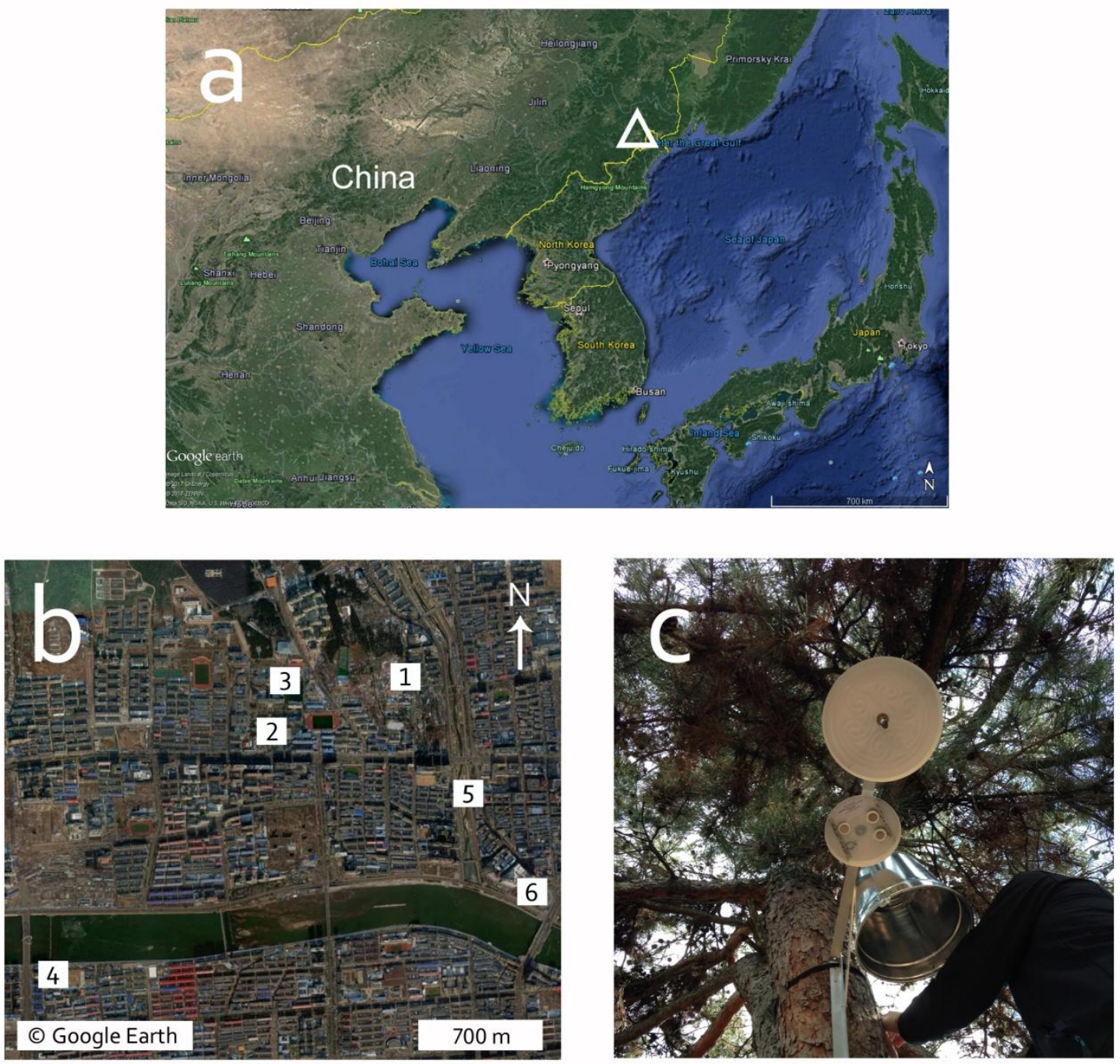

Figure 1. Panel (a) presents the location of the city of Yanji in northeast China (trigon), panel (b) shows the locations of the six study sites in Yanji, and panel (c) displays the passive sampling setup under rain shields attached to a tree trunk. At each site, air pollutants were measured in both tree-covered and open habitats. 
Table 1. Environmental variables and tree species determined at the six study sites in Yanji; distances of the air samplers from the nearest major road (Road dist.), \% canopy cover and \% sealed surface within $25 \mathrm{~m}$ radii from the sampling point in both habitat types (open and treecovered), dominant type of tree species and if they are evergreen (Ever.) or deciduous (Deci.), and biogenic volatile organic compound (BVOC) emission potential of the tree species (sources: Bao et al., 2008; Klinger et al., 2002).

\begin{tabular}{|c|c|c|c|c|c|c|c|c|c|}
\hline \multirow{2}{*}{$\begin{array}{l}\text { Site } \\
\text { nr. }\end{array}$} & \multicolumn{2}{|c|}{ Road dist. (m) } & \multicolumn{2}{|c|}{ Canopy (\%) } & \multicolumn{2}{|c|}{ Sealed $(\%)$} & \multirow{2}{*}{$\begin{array}{l}\text { Dominant } \\
\text { tree species }\end{array}$} & \multirow{2}{*}{$\begin{array}{l}\text { Ever. } \\
\text { /Deci. }\end{array}$} & \multirow{2}{*}{$\begin{array}{l}\text { BVOC emission } \\
\text { potential }\end{array}$} \\
\hline & Open & Tree & Open & Tree & Open & Tree & & & \\
\hline 1 & 400 & 395 & 0 & 87 & 78 & 8 & Pinus densiflora & ever. & strong (monoterpenes) \\
\hline 2 & 107 & 105 & 18 & 75 & 67 & 1 & Pinus densiflora & ever. & strong (monoterpenes) \\
\hline 3 & 378 & 364 & 8 & 77 & 11 & 15 & $\begin{array}{l}\text { Pinus densiflora } \\
\text { Ulmus pumila }\end{array}$ & $\begin{array}{l}\text { ever. } \\
\text { deci. }\end{array}$ & $\begin{array}{l}\text { strong (monoterpenes) } \\
\text { low (isoprene \& terpene) }\end{array}$ \\
\hline 4 & 98 & 100 & 0 & 60 & 57 & 29 & Populus spp. & deci. & depends on species \\
\hline 5 & 54 & 55 & 17 & 73 & 49 & 14 & Salix spp. & deci. & depends on species \\
\hline 6 & 54 & 54 & 12 & 86 & 74 & 20 & $\begin{array}{l}\text { Picea jezoensis } \\
\text { Picea koraiensis }\end{array}$ & $\begin{array}{l}\text { ever. } \\
\text { ever. }\end{array}$ & $\begin{array}{l}\text { med. (isopr.)/low (terp.) } \\
\text { med. (isopr.)/low (terp.) }\end{array}$ \\
\hline mean & 181.8 & 178.8 & 9.2 & 76.3 & $\begin{array}{l}55.9 \\
\end{array}$ & 14.4 & & & \\
\hline SD & 162.1 & 157.2 & 8.1 & 9.8 & 24.6 & 9.3 & & & \\
\hline
\end{tabular}

The PSDs were mounted for sampling PAHs inside (downward facing) 7 L zinc buckets. These buckets functioned as shelter shields from wind, rain and solar radiation (Fig. 1c). The $\mathrm{NO}_{2}, \mathrm{O}_{3}$ and $\mathrm{SO}_{2}$ samplers were mounted under plate-type rain shields (Fig. 1c). The samplers were attached 3-4 m above ground to lamp posts or similar poles in the open habitats and to tree trunks in the tree-covered habitats using a $40 \mathrm{~cm}$ long aluminum rack (Fig. 1c). Measurement period was from 13 May to 5 June 2015 (23 days). In Yanji this is early summer and plant leaves were practically fully emerged.

The percentage of canopy cover and sealed surface at each site was determined from satellite images (using Google Earth Pro, version 7.1.2.2041). The area covered by tree canopy and sealed surface within $25 \mathrm{~m}$ radii from the sampling point was determined in both habitat types. 
The canopy cover and sealed surface percentages ranged from 60 to $87 \%$ (mean $=76.3 \%, \mathrm{SD}=$ $9.8 \%$ ) and from 1 to $29 \%$ (mean $=14.4 \%, \mathrm{SD}=9.3 \%$ ), respectively, in tree-covered habitats (Table 1). In open habitats the canopy cover and sealed surface percentages ranged from 0 to 18 $\%($ mean $=9.2 \%, \mathrm{SD}=8.1 \%)$ and from 11 to $78 \%($ mean $=55.9 \%, \mathrm{SD}=24.6 \%)$, respectively (Table 1). The main tree species at the sampling sites were coniferous trees Pinus densiflora, Picea jezoensis and Picea koraiensis, and broad-leaf deciduous trees; Populus spp., Salix spp. and Ulmus pumila (Table 1).

Prevailing wind directions (long-term average) in Yanji are from the E, SE, and S (Meteoblue, 2017), but during our sampling campaign western and eastern winds dominated (Fig. 2). Our rather long sampling campaign is bound to diminish the impacts of daily changes in wind and thus wind direction is unlikely to cause systematic biases between and within our measuring sites. The monthly average temperature during the measurement period was typical in Yanji for this time of year; $17.0^{\circ} \mathrm{C}$.

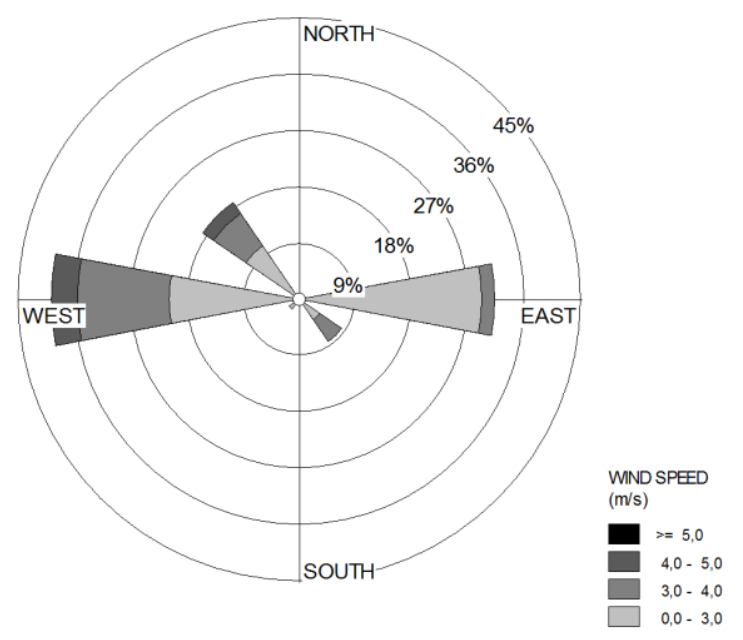

Figure 2. Wind rose depicting wind direction and speed during 13 May - 5 June 2015 in the city of Yanji, China (Yambian University measuring station). 


\subsection{Data analysis}

Data were analyzed using paired samples $t$-test to determine if there is a difference in pollution levels between the open and tree-covered habitats. We considered p-values $<0.05$ to indicate statistically significant differences between treatments. Where necessary, data were $\log _{10^{-}}$ transformed to stabilize the variance of individual properties. We applied linear regression to detect possible correlations between measured environmental variables and pollution levels between open and tree-covered habitats. Statistical analyses were performed using SPSS Statistics, version 22.

\section{Results}

Concentrations of total PAHs were, on average, 79.1\% $(p=0.008)$ higher in tree-covered habitats than in open habitats (Fig. 3a). Ten different PAHs were detected in the samples: naphthalene (NAP), acenaphthylene (ACY), acenaphthene (ACE), fluorene (FL), phenanthrene (PHE), anthracene (ANT), fluoranthene (FLT), pyrene (PYR), benzo[a]anthracene (BA-ANT) and chrysene (CHR) (Fig. 4). Concentrations of the following PAH constituents were, on average, higher in tree-covered habitats compared to open habitats: phenanthrene $(87.2 \%, p=$ $0.012)$, fluoranthene $(162.5 \%, p<0.001)$ and pyrene $(114.4 \%, p<0.001)$, while other constituents did not show significant differences between the two habitat types (Fig. 4). Concentrations of $\mathrm{NO}_{2}$ and $\mathrm{SO}_{2}$ did not differ between tree-covered and open habitats (Fig. 3b, c), while concentrations of $\mathrm{O}_{3}$ were, on average, 6.2\% $(p=0.039)$ lower in tree-covered compared to open habitats (Fig. 3d).

Canopy cover or sealed surface percentages did not correlate with variation in pollution concentrations between or within tree-covered and open habitats. Increasing distance (average of tree-covered and open sampling point at each site) from the nearest major road correlated 
negatively with $\mathrm{NO}_{2}$ concentrations $(R=-0.665, p=0.018) . \mathrm{NO}_{2}$ and $\mathrm{O}_{3}$ levels correlated negatively $(R=-0.641, p=0.025)$. Additionally, $\mathrm{NO}_{2}$ concentrations were positively correlated with the levels of total PAHs $(R=0.582, p=0.047)$, naphthalene $(R=0.709, p=0.010)$ and fluorene $(R=0.702, p=0.011)$.
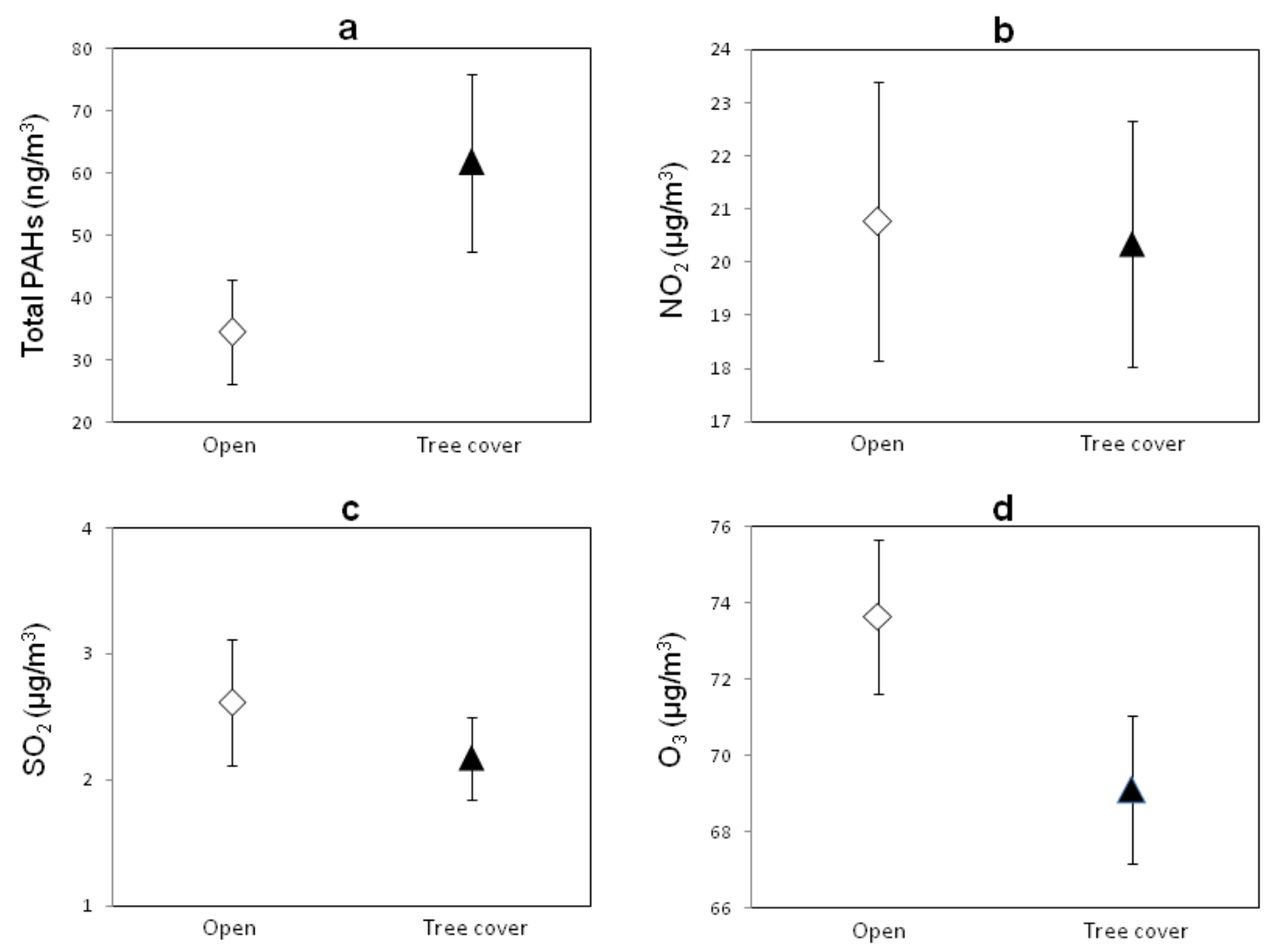

Figure 3. Concentrations (mean $\pm \mathrm{SE} ; n=6$ ) of (a) total gaseous PAHs, (b) $\mathrm{NO}_{2}$, (c) $\mathrm{SO}_{2}$, and (d) $\mathrm{O}_{3}$ in open (diamonds) and tree-covered (triangles) habitats. 
Yli-Pelkonen et al. 2018
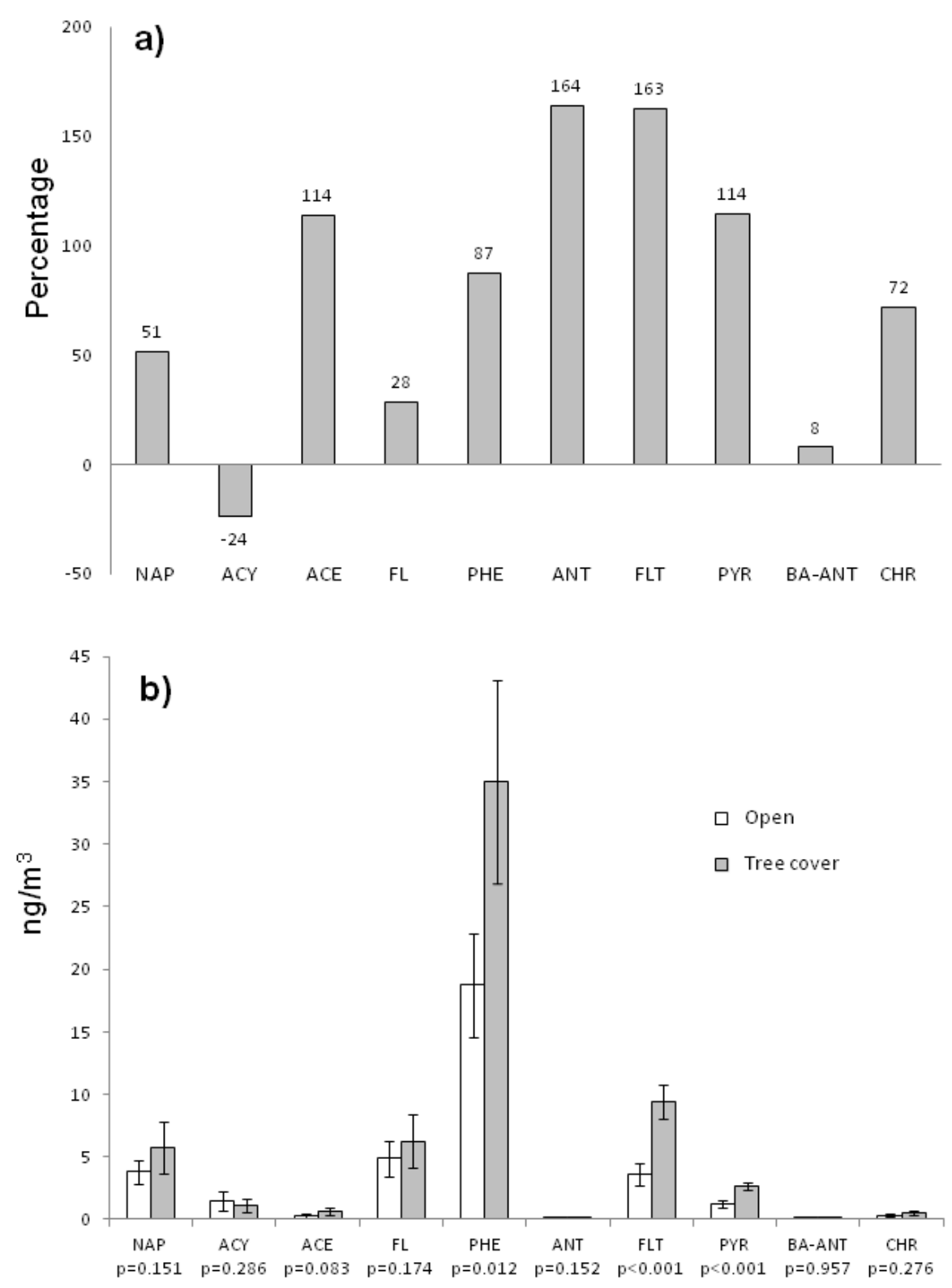

Figure 4. Panel (a) depicts the relative impact of tree-cover (grey bars, in percentages) on the levels of ten PAH constituents with the zero-line (x-axis) presenting PAH levels at the open habitats. The positive percentage value (values above the zero line) means that the mean PAH concentrations were higher in tree-covered habitats than in open habitats, and the negative percentage value (ACY) means that the mean concentrations were lower in tree-covered habitats 
compared to open habitats. Panel (b) shows actual concentrations (y-axis: $\mathrm{ng} \mathrm{m}^{-3} ;$ mean $\pm \mathrm{SE} ; n$ =6) of the PAH constituents in open (white bars) and tree-covered (grey bars) habitats. NAP = naphthalene, $\mathrm{ACY}=$ acenaphthylene, $\mathrm{ACE}=$ acenaphthene $\mathrm{FL}=$ fluorene, $\mathrm{PHE}=$ phenanthrene, $\mathrm{ANT}=$ anthracene, $\mathrm{FLT}=$ fluoranthene, $\mathrm{PYR}=$ pyrene, $\mathrm{BA}-\mathrm{ANT}=$ benzo$[\mathrm{a}]$ anthracene, $\mathrm{CHR}=$ chrysene). P-values are presented below the PAH constituents.

\section{Discussion}

\subsection{PAH concentrations in tree-covered and open habitats}

We found substantially higher concentrations of total gaseous PAHs (and individual PAH constituents PHE, FL and PYR) in tree-covered compared to open habitats in urban park environments in Yanji, northeast China. Thus, regarding PAHs, results support our hypothesis that air quality is not improved in tree-covered urban habitats compared to nearby treeless habitats. It is also noticeable that the PAH concentrations were substantially higher in treecovered than in open habitats, even though the uptake rates of PAHs into the PSDs can be slightly lower in tree-covered habitats than in open habitats implying an underestimation of PAH concentrations in tree-covered habitats (see Viippola et al., 2016). While trees are known to intercept PAHs (e.g. Wagrowski and Hites, 1997; De Nicola et al., 2017), the effect of foliagemediated absorption was likely masked by other canopy-related phenomena that can elevate concentrations of gaseous pollutants, including PAHs, below tree canopies (results of the current study, see also Viippola et al. (2016)).

Only a few studies have reported higher air pollutant concentrations under tree canopies compared to nearby treeless areas (e.g. Harris and Manning, 2010; Viippola et al., 2016; YliPelkonen et al., 2017c). One potential factor causing higher air pollutant levels under tree 
canopies is diminished air ventilation inside tree-covered habitats (Belcher et al., 2012; Gromke and Ruck, 2009; Renaud et al., 2011; Wuyts et al., 2008), which can result in elevated air pollutant concentrations under the canopy (i.e. "trapping effect"), as has been shown especially in highly polluted near-road environments (Viippola et al., 2016, 2018; Vos et al., 2013; YliPelkonen et al., 2017c). In open, treeless habitats, wind dilutes the air pollutants more promptly.

Another potential explanation for the increased PAH concentrations below tree canopies may associate with gas exchange between air and the soil, an important process related to the lifecycle of organic pollutants, such as PAHs (Cousins et al., 1999). According to Lang et al. (2007), gas exchange between air and the soil is the principal process removing PAHs from the atmosphere and simultaneously the most important process leading to PAH pollution of soils. Moreover, both gaseous and particle-bound PAHs deposit on plant surfaces and are subsequently deposited to the soil via litter fall and interception events. Consequently, tree cover increases PAH deposition into the soil compared to similar open areas (Horstmann et al., 1997; Howsam et al., 2001; Matzner, 1984; Peng et al., 2012). While PAHs can accumulate from air to the soil, especially during winter due to low temperatures and high emissions from combustion (Wang et al., 2011), they are also volatilized from soil back to the atmosphere, especially during summer with higher temperatures and rainfall (Lang et al., 2007; Sweetman et al., 2005; Wang et al., 2011).

In their study in Gothenburg, Sweden, Klingberg et al. (2017) found no difference in total PAH (both gaseous and particle-bound) and phenanthrene concentrations between a vegetated (deciduous trees) and non-vegetated habitat, but found lower concentrations of total particlebound PAHs and benzo[a]pyrene within the vegetated habitat. However, total PAH/phenanthrene concentrations were considerably higher after than before leaf-emergence at the vegetated habitat 
of the site (Klingberg et al., 2017). This suggests that tree leaves do not remove gaseous PAHs effectively, but may, in combination with PAHs released from the soil during summer and reduced ventilation under tree canopy - especially with leaves - increase the gaseous PAH concentrations under the tree canopy, as suggested in Viippola et al. (2016). On the contrary, Terzaghi et al. (2015) reported slightly lower total PAH concentrations in a small forest than in a nearby clearing within an urban site in Como, Northern Italy, while particle-bound PAH levels were higher in the forest. In their case study in Spain, De Nicola et al. (2017) found that a evergreen conifer tree (Pinus pinaster) can accumulate higher amounts of low and medium molecular weight PAHs than a deciduous tree (Quercus robur) of the same size. Although about half of the sites in our current study were dominated by evergreen conifers and half by deciduous broadleaf trees, we could not detect differences in PAH capture by different types of tree species as we did not observe actual PAH capture, but the measured PAH concentrations were rather uniformly higher in tree-covered habitats compared to open habitats.

The concentrations of gaseous PAHs were considerably higher in the current study in Yanji, northeast China, than in Viippola et al. (2016), where study sites were in urban near-road park environments in Finland. However, target values for the protection of human health regarding the detected PAHs are not available, which prevents us from assessing the potential health risks of the detected PAH concentrations. Especially the levels of phenanthrene were considerably high and the difference of its levels between open and tree-covered habitats in Yanji is particularly large. Phenanthrene irritates skin, eyes and the respiratory tract, but due to the lack of human data it is not classifiable as a human carcinogen and the experimental animal data is inadequate, based on only one study (PubChem, 2018). However, the overall pattern of trees in 
Yli-Pelkonen et al. 2018

increasing PAH concentrations seems to be the same, irrespective of differences in ambient PAH concentrations between Helsinki and Yanji.

We suggest that the higher PAH concentrations in tree-covered habitats in our current study are best explained by the trapping of PAHs under the foliage due to reduced ventilation, as well as by the accumulation of PAHs into the soil via gas exchange between air and the soil. Furthermore, subsequent evaporation of PAHs from soil back into the air can enable the development of high summertime PAH concentrations within tree canopies (see Viippola et al., 2016). In our current study, the lower percentage of sealed surface around the sampling points in tree-covered habitats compared to open habitats may also slightly elevate PAH concentrations under canopies. Viippola et al. (2016) did not find correlations between plant properties and ambient PAH concentrations in tree-covered sites. In line with that, differences in PAH concentrations between tree-covered and open habitats in the current study in Yanji did not correlate with canopy cover percentage at the sites, although tree canopies significantly increased the concentrations of total PAHs and certain PAH constituents. These findings suggest that even a relatively small amount of canopy cover may result in higher gaseous PAH concentrations.

\section{2. $\mathrm{NO}_{2}, \mathrm{O}_{3}$ and $\mathrm{SO}_{2}$ concentrations in tree-covered and open habitats}

We showed that concentrations of $\mathrm{NO}_{2}$ and $\mathrm{SO}_{2}$ are not reduced by tree-cover in Yanji, while the concentrations of $\mathrm{O}_{3}$ are. However, $\mathrm{SO}_{2}$ concentrations were so low that the potential effect of trees may not be detectable at such levels. The similar $\mathrm{NO}_{2}$ levels between tree-covered and open habitats support our hypothesis and earlier discoveries showing either no diminishment or a slight increase in $\mathrm{NO}_{2}$ levels by urban tree cover (Harris and Manning, 2010; Irga et al., 2015; Setälä et al., 2013; Viippola et al., 2018; Yli-Pelkonen et al., 2017a, b, c). On the other hand, our 
results in Yanji are not in line with earlier studies indicating some diminishment in $\mathrm{NO}_{2}$ by the tree canopy (García-Gómez et al., 2016; Grundström and Pleijel, 2014; Fantozzi et al., 2015; Klingberg et al., 2017; Rao et al., 2014; Yin et al., 2011).

Lower concentrations of $\mathrm{O}_{3}$ under trees in this study corroborates our hypothesis and previous outcomes from empirical and model-based studies (Baumgardner et al., 2012; García-Gómez et al., 2016; Harris and Manning, 2010; Selmi et al., 2016; Yli-Pelkonen et al., 2017a), but to some extent disagrees with results by Grundström and Pleijel (2014), Fantozzi et al. (2015) and YliPelkonen et al. (2017b).

Thus, the influence of trees on $\mathrm{NO}_{2}$ and $\mathrm{O}_{3}$ concentrations is likely linked to configuration and species of trees, climate and microclimate, and distance from pollution sources. For example, in their study in Rome, Italy, Manes et al. (2012) estimated that both conifers and deciduous broadleaves can be relatively efficient in $\mathrm{O}_{3}$ removal in summer season. Although the ozone removal estimates are not available for the dominant tree species in our current study, our sitespecific ozone results are in line with the estimates of Manes et al. (2012) as $\mathrm{O}_{3}$ levels were, regardless of the tree species or sites, almost uniformly lower in tree-covered habitats than in open habitats. Moreover, the formation of $\mathrm{O}_{3}$ in the lower atmosphere is regulated by photolysis, which occurs more frequently in higher temperatures (Cardelino and Chameides, 1990; Churkina et al., 2017; Finlayson-Pitts and Pitts, 1997; Paoletti et al., 2014). Diminished solar radiation and typically lower mean daily temperatures below tree cover (Shashua-Bar and Hoffman, 2004; Renaud et al., 2011; Lehmann et al., 2014) may also reduce $\mathrm{O}_{3}$ levels in within tree canopies (Cardelino and Chameides, 1990). Considering this, it is possible that absorption of $\mathrm{O}_{3}$ by trees is not the only factor contributing to diminished levels of $\mathrm{O}_{3}$ in canopy-covered areas, but that lowered solar radiation and temperatures may also play a role in this. The decline in $\mathrm{NO}_{2}$ 
concentrations with distance from the nearest major road, as well as the negative correlation between the concentrations of $\mathrm{NO}_{2}$ and $\mathrm{O}_{3}$, point that road traffic is the main source of $\mathrm{NO}_{2}$ in our study setup (Clements et al., 2009; Setälä et al., 2013; Yli-Pelkonen et al., 2017b). When traffic-derived $\mathrm{NO}_{\mathrm{x}}$ concentrations are low, $\mathrm{NO}_{\mathrm{x}}$ reacts to form ozone, while at elevated concentrations, $\mathrm{NO}_{\mathrm{x}}$ catalyzes ozone depletion (e.g. Rodes and Holland, 1981).

As also BVOCs contribute to ozone formation, it is possible that varying BVOC emission potential among the tree species at the study sites (Table 1) had an impact on $\mathrm{O}_{3}$ concentrations. However, as we did not measure BVOC concentrations in the current study, and species-specific BVOC emissions are known the vary depending several factors (e.g. region, location, season, weather, stress conditions) (e.g. Klinger et al., 2002), it is difficult to know how the potential BVOC emissions may have affected the $\mathrm{NO}_{\mathrm{x}} / \mathrm{O}_{3}$ dynamics at the sites. Moreover, we did not observe a clear pattern between BVOC emission potential estimates and $\mathrm{O}_{3}$ reduction in the treecovered habitats.

In general, $\mathrm{O}_{3}$ concentrations in Yanji are clearly higher than for instance in the hemi-boreal city of Helsinki, Finland (Yli-Pelkonen et al., 2017b), and in the Mid-Atlantic city of Baltimore, USA (Yli-Pelkonen et al., 2017a), both being markedly larger cities than Yanji. Regarding $\mathrm{NO}_{2}$, the aforementioned "trapping effect" can also mask the potential air purification effect by trees, so that measured $\mathrm{NO}_{2}$ concentrations are not reduced in tree-covered habitats compared to open habitats, although the canopy should absorb $\mathrm{NO}_{2}$ (Setälä et al., 2013; Yli-Pelkonen et al., 2017c).

To summarize, our findings indicate that tree cover in urban parks does not necessarily contribute to uniform air quality improvements regarding gaseous air pollutants. The tree canopy did not affect the studied gaseous air pollutants similarly, which suggests that reduced ventilation 
under the tree canopy may not be the only explanatory factor of higher PAH concentrations under the tree canopy compared to open areas. Since we had three response types of how the tree canopy affected air pollutant concentrations; (i) increased (PAHs), (ii) decreased $\left(\mathrm{O}_{3}\right)$, and (iii) indifferent effect $\left(\mathrm{NO}_{2}, \mathrm{SO}_{2}\right)$, the studied gaseous air pollutants clearly have their own special features that result in variable effects by the tree canopy. For instance, PAHs, as organic compounds, have an important air-soil gas exchange process potentially contributing substantially to higher PAH concentrations under tree canopies compared to open habitats, whereas $\mathrm{NO}_{2}, \mathrm{SO}_{2}$ and $\mathrm{O}_{3}$ as inorganic compounds do not have such a feature. Moreover, it is well known that uptake pathways of PAHs by plants are different from those of $\mathrm{NO}_{2}, \mathrm{SO}_{2}$ and $\mathrm{O}_{3}$. For instance, PAHs can be intercepted from the air on the plant leaf surfaces and eventually diffused into the leaf interior, but leaves can also capture especially gaseous PAHs from the air via stomata (De Nicola et al., 2017.). $\mathrm{NO}_{2}, \mathrm{SO}_{2}$ and $\mathrm{O}_{3}$, on the other hand, are captured from the air mainly through the stomata into the plant leaves. Further, $\mathrm{O}_{3}$ differs from the other studied gases so that it may occur to a lesser extent under tree canopies due to a lack of photolysis, but it may also be absorbed more efficiently by trees than the other air pollutants in our study.

\section{Conclusions}

The results of our study from a northeastern city in China imply that tree canopies in urban parks can increase concentrations of gaseous PAHs and diminish $\mathrm{O}_{3}$ concentrations, while the effects of trees on $\mathrm{NO}_{2}$ and $\mathrm{SO}_{2}$ concentrations are indifferent. Further, our results suggest that the gaseous air pollutants studied are affected by tree-cover via various mechanisms. While trees can potentially uptake all the studied air pollutants, at least to some extent, this effect was detectable only for $\mathrm{O}_{3}$. The increased gaseous PAH concentrations under the tree canopy confirmed our earlier observation of this phenomenon, which likely relates to a combination of reduced 
ventilation and air-soil interactions under tree canopies. The lowered $\mathrm{O}_{3}$ levels within treecovered habitats can result from a combination of uptake of $\mathrm{O}_{3}$ by trees and lower temperatures and solar radiation in tree-covered habitats compared to open habitats. Consequently, despite the various, well-known ecosystem services provided by urban vegetation, such as recreation, aesthetic pleasure and mitigation of the urban heat island effect (Scott et al., 2017), urban trees may also provide disservices for urbanites via increased PAH concentrations.

\section{Acknowledgements}

This study was funded by the Maj and Tor Nessling Foundation and the Helsinki Metropolitan Region Urban Research Program. We thank Miao Wang, Junjie Jin, Lei Qin, Jian Zhang and Ms. $\mathrm{Xu}$ for their help in the field, Suvi Survo for assistance in laboratory work, and Johan Kotze for checking the language.

\section{References}

Anttila, P., Tuovinen, J.-P., Niemi, J.V., 2011. Primary $\mathrm{NO}_{2}$ emissions and their role in the development of $\mathrm{NO}_{2}$ concentrations in a traffic environment. Atmospheric Environment 45, 986992.

Atkinson, R., 2000. Atmospheric chemistry of VOCs and $\mathrm{NO}_{\mathrm{x}}$. Atmospheric Environment 34, 2063-2101.

Ayers, G.P., Keywood, M.D., Gillett, R., Manins, P.C., Malfroy, H., Bardsley, T., 1998.

Validation of passive diffusion samplers for $\mathrm{SO}_{2}$ and $\mathrm{NO}_{2}$. Atmospheric Environment 32, 35873592.

Bakker, M.I., Koerselman, J.W., Tolls, J., Kolloffel, C., 2001. Localization of deposited polycyclic aromatic hydrocarbons in leaves of Plantago. Environmental Toxicology and Chemistry / SETAC 20, 1112-1116.

Bao, H., Kondo, A., Kaga, A., Tada, M., Sakaguti, K., Inoue, Y., Shimodam, Y., Narumi, D., Machimura, T., 2008. Biogenic volatile organic compound emission potential of forests and paddy fields in the Kinki region of Japan. Environmental Research 106, 156-169. 
Baumgardner, D., Varela, S., Escobedo, F.J., Chacalo, A., Ochoa, C., 2012. The role of periurban forest on air quality improvement in the Mexico City megalopolis. Environmental Pollution 163, 174-183.

Beckett, K.P., Freer-Smith, P.H., Taylor, G., 2000. The capture of particulate pollution by trees at five contrasting urban sites. Arboricultural Journal 24, 209-230.

Belcher, S.E., Harman, I.N., Finnigan, J.J., 2012. The wind in the willows: flows in forest canopies in complex terrain. Annual Review of Fluid Mechanics 44, 479-504.

Boström, C.E., Gerde, P., Hanberg, A., Jernström, B., Johansson, C., Kyrklund, T., Rannug, A., Törnqvist, M., Victorin, K., Westerholm, R., 2002. Cancer risk assessment, indicators, and guidelines for polycyclic aromatic hydrocarbons in the ambient air. Environmental Health Perspectives 110 Suppl 3, 451-488.

Busby, W.F., Goldman, M.E., Newberne, P.M., Wogan, G.N., 1984. Tumorigenicity of fluoranthene in a newborn mouse lung adenoma bioassay. Carcinogenesis 5, 1311.

Calfapietra, C., Fares, S., Manes, F., Morani, A., Sgrigna, G., Loreto, F., 2013. Role of Biogenic Volatile Compounds (BVOC) emitted by urban trees on ozone concentration in cities: A review. Environmental Pollution 183, 71-80.

Cardelino, C.A., Chameides, W.L., 1990. Natural hydrocarbons, urbanization, and urban zone. Journal of Geophysical Research 95, 13971-13979.

Chameides, W.L., Fehsenfeld, F., Rodgers, M.O., Cardelino, C., Martinez, J., Parrish, D., Lonneman, W., Lawson, D.R., Rasmussen, R.A., Zimmerman, P., Greenberg, J., Middleton, P., Wang, T., 1992. Ozone precursor relationships in the ambient atmosphere. Journal of Geophysical Research: Atmospheres 97, 6037-6055.

Chameides, W.L., Lindsay, R.W., Richardson, J., Kiang, C.S., 1988. The role of biogenic hydrocarbons in urban photochemical smog: Atlanta as a case study. Science 241, 1473-1475.

Chaparro-Suarez, I.G., Meixner, F.X., Kesselmeier, J., 2011. Nitrogen dioxide $\left(\mathrm{NO}_{2}\right)$ uptake by vegetation controlled by atmospheric concentrations and plant stomatal aperture. Atmospheric Environment 45, 5742-5750.

Churkina, G., Kuik, F., Bonn, B., Lauer, A., Grote, R., Tomiak, K., Butler, T.M., 2017. Effect of VOC emissions from vegetation on air quality in Berlin during a heatwave. Environmental Science \& Technology 51, 6120-6130.

Clements, A.L., Jia, Y., Denbleyker, A., McDonald-Buller, E., Fraser, M.P., Allen, D.T., Collins, D.R., Michel, E., Pudota, J., Sullivan, D., Zhu, Y., 2009. Air pollutant concentrations near three Texas roadways, Part II: Chemical characterization and transformation of pollutants. Atmospheric Environment 43, 4523-4534. 
Cousins, I.T., Beck, A.J., Jones, K.C., 1999. A review of the processes involved in the exchange of semi-volatile organic compounds (SVOC) across the air-soil interface. Science of the Total Environment 228, 5-24.

Cranor, W.L., Alvarez, D.A., Huckins, J.N., Petty, J.D., 2009. Uptake rate constants and partition coefficients for vapor phase organic chemicals using semipermeable membrane devices (SPMDs). Atmospheric Environment 43, 3211-3219.

De Nicola, F., Concha Graña, E., López Mahía, P., Muniategui Lorenzo, S., Prada Rodríguez, D., Retuerto, R., Carballeira, A., Aboal, J.R., Fernández, Á., 2017. Evergreen or deciduous trees for capturing PAHs from ambient air? A case study. Environmental Pollution 221, 276-284.

Duncan, B.N., Lamsal, L.N., Thompson, A.M., Yoshida, Y., Lu, Z., Streets, D.G., Hurwitz, M.M., Pickering, K.E., 2016. A space-based, high-resolution view of notable changes in urban $\mathrm{NO}_{\mathrm{x}}$ pollution around the world (2005-2014). Journal of Geophysical Research 121, 976-996.

EEA, 2016. Air quality in Europe - 2016 report. European Environment Agency EEA Report No 28/2016. Retrieved 31 December, 2017 from - http://www.eea.europa.eu/publications/airquality-in-europe-2016

Fantozzi, F., Monaci, F., Blanusa, T., Bargagli, R., 2015. Spatio-temporal variations of ozone and nitrogen dioxide concentrations under urban trees and in a nearby open area. Urban Climate, $12,119-127$.

Ferm, M., 2001. Validation of a diffusive sampler for ozone in workplace atmospheres according to EN838. Proc. from International Conference Measuring Air Pollutants by Diffusive Sampling, Montpellier, France 26-28 September 2001. pp. 298-303.

Ferm, M., Rodhe, H., 1997. Measurements of air concentrations of $\mathrm{SO}_{2}, \mathrm{NO}_{2}$ and $\mathrm{NH}_{3}$ at rural and remote sites in Asia. Journal of Atmospheric Chemistry 27, 17-29.

Ferm, M., Svanberg, P.-A., 1998. Cost-efficient techniques for urban- and background measurements of $\mathrm{SO}_{2}$ and $\mathrm{NO}_{2}$. Atmospheric Environment 32, 1377-1381.

Finlayson-Pitts, B.J., Pitts, J.N. Jr., 1997. Tropospheric air pollution: ozone, airborne toxics, polycyclic aromatic hydrocarbon, and particles. Science 276, 1045-1052.

García-Gómez, H., Aguillaume, L., Izquieta-Rojano, S., Valiño, F., Àvila, A., Elustondo, D., Santamaría, J.M., Alastuey, A., Calvete-Sogo, H., Gonzáles-Fernández, I., Alonso, R., 2016. Atmospheric pollutants in peri-urban forests of Quercus ilex: evidence of pollution abatement and threats for vegetation. Environmental Science and Pollution Research 23, 6400-6413.

Gromke, C., Ruck, B., 2009. On the impact of trees on dispersion processes of traffic emissions in street canyons. Boundary-Layer Meteorology 131, 19-34. 
Grundström, M., Pleijel, H., 2014. Limited effect of urban tree vegetation on $\mathrm{NO}_{2}$ and $\mathrm{O}_{3}$ concentrations near a traffic route. Environmental Pollution 189, 73-76.

Harris, T.B., Manning, W.J., 2010. Nitrogen dioxide and ozone levels in urban tree canopies. Environmental Pollution 158, 2384-2386.

Honkonen, O., Rantalainen A.-L., 2016. Transport of urban-derived organic contaminants into a boreal lake: a case study with passive samplers. Boreal Environmental Research 21, 87-100.

Horstmann, M., Bopp, U., McLachlan, M.S., 1997. Comparison of the bulk deposition of $\mathrm{PCDD} / \mathrm{F}$ in a spruce forest and an adjacent clearing. Chemosphere 34, 1245-1254.

Howsam, M., Jones, K.C., Ineson, P., 2001. Dynamics of PAH deposition, cycling and storage in a mixed-deciduous (Quercus-Fraxinus) woodland ecosystem. Environmental Pollution 113, 163176.

Hu, Y., Zhao, P., Niu, J., Sun, Z., Zhu, L., Ni, G., 2016. Canopy stomatal uptake of $\mathrm{NO}_{\mathrm{x}}, \mathrm{SO}_{2}$ and $\mathrm{O}_{3}$ by mature urban plantations based on sap flow measurement. Atmospheric Environment $125,165-177$.

Huckins, J.N., Tubergen, M., Manuweera, G., 1990. Semipermeable membrane devices containing model lipid: A new approach to monitoring the bioavailability of lipophilic contaminants and estimating their bioconcentration potential. Chemosphere 20, 533-552.

HSY (Helsinki Region Environmental Services Authority), 2014. Ilmanlaatu pääkaupunkiseudulla vuonna 2013 (Air Quality in the Helsinki Metropolitan Area in 2013). HSY publications 3/2014. [in Finnish with an abstract in English] Retrieved 1 January, 2018 from https://www.hsy.fi/sites/Esitteet/EsitteetKatalogi/Julkaisusarja/3_2014_Ilmanlaatu_paakaupunkis eudulla_2013.pdf

IARC (International Agency for Research of Cancer), 2010. Some non-heterocyclic polyaromatic hydrocarbons and some related exposures. IARC Monographs on the evaluation of carcinogenic risks to humans, vol. 92. World Health Organization. 853 p. Retrieved 1 January, 2018 from - https://monographs.iarc.fr/ENG/Monographs/vol92/mono92.pdf

Irga, P.J., Burchett, M.D., Torpy F.R., 2015. Does urban forestry have a quantitative effect on ambient air quality in an urban environment? Atmospheric Environment 120, 173-181.

Jouraeva, V.A., Johnson, D.L., Hassett, J.P., Nowak, D.J., 2002. Differences in accumulation of PAHs and metals on the leaves of Tiliaxeuchlora and Pyrus calleryana. Environmental Pollution 120, 331-338.

Kampa, M., Castanas, E., 2008. Human health effects of air pollution. Environmental Pollution $151,362-367$. 
Klingberg, J., Broberg, M., Strandberg, B., Thorsson, P., Pleijel, H., 2017. Influence of urban vegetation on air pollution and noise exposure - A case study in Gothenburg, Sweden. Science of the Total Environment 599-600, 1728-1739.

Klinger, L.F., Lie, Q.-J., Guenther, A.B., Greenberg, J.P., Baker, B., Bai, J.-H., 2002. Assessment of volatile organic compound emissions from ecosystems of China. Journal of Geophysical Research 107 (D21), 4603.

Krupa, S.V., Legge, A.H., 2000. Passive sampling of ambient, gaseous air pollutants: An assessment from an ecological perspective. Environmental Pollution 107, 31-45.

Krämer, U., Koch, T., Ranft, U., Ring, J., Behrendt, H., 2000. Traffic-related air pollution is associated with atopy in children living in urban areas. Epidemiology 11, 64-70.

Lang, C., Tao, S., Wang, X., Zhang, G., Li, J., Fu, J., 2007. Seasonal variation of polycyclic aromatic hydrocarbons (PAHs) in Pearl River Delta region, China. Atmospheric Environment $41,8370-8379$.

Lehmann, I., Mathey, J., Rössler, S., Bräuer, A., Goldberg, V., 2014. Urban vegetation structure types as a methodological approach for identifying ecosystem services - Application to the analysis of micro-climatic effects. Ecological Indicators 42, 58-72.

Loreto, F., Schnitzler, J.-P., 2010. Abiotic stresses and induced BVOCs. Trends in Plant Science $15,154-166$.

Manes, F., Incerti, G., Salvatori, E., Vitale, M., Ricotta, C., Costanza, R., 2012. Urban ecosystem services: tree diversity and stability of tropospheric ozone removal. Ecological Applications 22, 349-360.

Marr, L.C., Kirchstetter, T.W., Harley, R.A., Miguel, A.H., Hering, S.V., Hammond, S.K., 1999. Characterization of polycyclic aromatic hydrocarbons in motor vehicle fuels and exhaust emissions. Environmental Science \& Technology 33, 3091-3099.

Matzner, F., 1984. Annual rates of deposition of polycyclic aromatic hydrocarbons in different forest ecosystems. Water, Air, and Soil Pollution 21, 425-434.

Meteoblue, 2017. Climate Yanji. Retrieved 1 July, 2017 from https://www.meteoblue.com/en/weather/forecast/modelclimate/yanji_china_10303676

Morani, A., Nowak, D.J., Hirabayahsi, S., Calfapietra, C., 2011. How to select the best tree planting locations to enhance air pollution removal in the MillionTreesNYC initiative. Environmental Pollution 159, 1040-1047.

Nowak, D.J., Crane, D.E., Stevens, J.C., 2006. Air pollution removal by urban trees and shrubs in the United States. Urban Forestry \& Urban Greening 4, 115-123. 
Paoletti, E., De Marco, A., Beddows, D.C.S., Harrison, R.M., Manning, W.J., 2014. Ozone levels in European and USA cities are increasing more than at rural sites, while peak values are decreasing. Environmental Pollution 192, 295-299.

Pataki, D.E., Alberti, M., Cadenasso, M.L., Felson, A.J., McDonnell, M.J., Pincetl, S., Pouyat, R.V., Setälä, H., Whitlow, T.H., 2013. City trees: Urban greening needs better data. Nature 502, 624.

Pataki, D.E., Carreiro, M.M., Cherrier, J., Grulke, N.E., Jennings, V., Pincetl, S., Pouyat, R.V., Whitlow, T.H., Zipperer, W.C., 2011. Coupling biogeochemical cycles in urban environments: ecosystem services, green solutions, and misconceptions. Frontiers in Ecology and the Environment 9, 27-36.

Peng, C., Ouyang, Z., Wang, M., Chen, W., Jiao, W., 2012. Vegetative cover and PAHs accumulation in soils of urban green space. Environmental Pollution 161, 36-42.

Pfister, G.G., Walters, S., Lamarque, J.-F., Fast, J., Barth, M.C., Wong, J., Done, J., Holland, G., Bruyère, C.L., 2014. Projections of future summertime ozone over the U.S. Journal of Geophysical Research 119, 5559-5582.

Piccardo, M.T., Stella, A., Pala, M., Balducci, D., Valerio, F., 2010. Field use of semipermeable membrane devices (SPMDs) for passive air sampling of polycyclic aromatic hydrocarbons: Opportunities and limitations. Atmospheric Environment 44, 1947-1951.

PubChem (Open Chemistry Database), 2018. Phenanthrene. Retrieved 23 July, 2018 from https://pubchem.ncbi.nlm.nih.gov/compound/phenanthrene.

Rao, M., George, L.A., Rosenstiel, T.N., Shandas, V., Dinno, A., 2014. Assessing the relationship among urban trees, nitrogen dioxide, and respiratory health. Environmental Pollution 194, 96-104.

Renaud, V., Innes, J.L., Dobbertin, M., Rebetez, M., 2011. Comparison between open-site and below-canopy climatic conditions in Switzerland for different types of forests over 10 years (1998-2007). Theoretical and Applied Climatology 105, 119-127.

Rodes, C.E., Holland, D.M., 1981. Variations of $\mathrm{NO}, \mathrm{NO}_{2}$ and $\mathrm{O}_{3}$ concentrations downwind of a Los Angeles freeway. Atmospheric Environment 15, 243-250.

Rondón, A., Granat, L., 1994. Studies on the dry deposition of $\mathrm{NO}_{2}$ to coniferous species at low $\mathrm{NO}_{2}$ concentrations. Tellus 46B, 339-352.

Scott, A.A., Zaitchik, B., Waugh, D.W., O'Meara, K., 2017. Intraurban temperature variability in Baltimore. Journal of Applied Meteorology and Climatology 56, 159-171. 
Selmi, W., Weber, C., Rivière, E., Blond, N., Mehdi, L., Nowak, D., 2016. Air pollution removal by trees in public green spaces in Strasbourg city, France. Urban Forestry \& Urban Greening 17, 192-201.

Sjöberg, K., Lövblad, G., Ferm, M., Ulrich, E., Cecchini, S., Dalstein, L., 2001. Ozone measurements at forest plots using diffusive samplers. Proc. from International Conference Measuring Air Pollutants by Diffusive Sampling, Montpellier, France 26-28 September 2001. pp. 116-123.

Setälä, H., Viippola, V., Rantalainen, A.-L., Pennanen, A., Yli-Pelkonen, V., 2013. Does urban vegetation mitigate air pollution in northern conditions? Environmental Pollution 183, 104-112.

Shashua-Bar, L., Hoffman, M.E., 2004. Quantitative evaluation of passive cooling of the UCL microclimate in hot regions in summer, case study: urban streets and courtyards with trees. Building and Environment 39, 1087-1099.

Shen, H., Tao, S., Wang, R., Wang, B., Shen, G., Li, W., Su, S., Huang, Y., Wang, X., Liu, W., Li, B., Sun, K., 2011. Global time trends in PAH emissions from motor vehicles. Atmospheric Environment 45, 2067-2073.

Simonich, S., Hites, R., 1994. Importance of vegetation in removing polycyclic aromatic hydrocarbons from the atmosphere. Nature 370, 49-51.

Slovik, S., Siegmund, A., Kindermann, G., Riebling, R., Balázs, Á., 1995. Stomatal $\mathrm{SO}_{2}$ uptake and sulfate accumulation in needles of Norway spruce stands (Picea abies) in Central Europe. Plant and Soil 168-169, 405-419.

Sweetman, A.J., Valle, M.D., Prevedouros, K., Jones, K.C., 2005. The role of soil organic carbon in the global cycling of persistent organic pollutants (POPs): interpreting and modelling field data. Chemosphere 60, 959-972.

Söderström, H., Hajšlová, J., Kocourek, V., Siegmund, B., Kocan, A., Obiedzinski, M.W., Tysklind, M., Bergqvist, P., 2005. PAHs and nitrated PAHs in air of five European countries determined using SPMDs as passive samplers. Atmospheric Environment 39, 1627-1640.

Takahashi, M., Higaki, A., Nohno, M., Kamada, M., Okamura, Y., Matsui, K., Kitani, S., Morikawa, H., 2005. Differential assimilation of nitrogen dioxide by 70 taxa of roadside trees at an urban pollution level. Chemosphere 61, 633-639.

Terzaghi, E., Zacchello, G., Scacchi, M., Raspa, G., Jones, K.C., Cerabolini, B., Di Guardo, A., 2015. Towards more ecologically realistic scenarios of plant uptake modelling for chemicals: PAHs in a small forest. Science of The Total Environment 505, 329-337. 
Tong, Z., Whitlow, T. H., MacRae, P. F., Landers, A. J., Harada, Y., 2015. Quantifying the effect of vegetation on near-road air quality using brief campaigns. Environmental Pollution, 201, 141-149.

Uysal, N., Schapira, R.M., 2003. Effects of ozone on lung function and lung diseases. Current Opinion in Pulmonary Medicine 8, 144-150.

Viippola, V., Rantalainen, A.-L., Yli-Pelkonen, V., Tervo, P., Setälä, H., 2016. Gaseous polycyclic aromatic hydrocarbon concentrations are higher in urban forests than adjacent open areas during summer but not in winter - Exploratory study. Environmental Pollution 208, 233240.

Viippola, V., Whitlow, T., Zhao, W., Yli-Pelkonen, V., Mikola, J., Pouyat, R., Setälä, H., 2018. The effects of trees on air pollutant levels in peri-urban near-road environments. Urban Forestry \& Urban Greening 30, 62-71.

Vos, P.E.J., Maiheu, B., Vankerkom, J., Janssen, S., 2013. Improving local air quality in cities: To tree or not to tree? Environmental Pollution 183, 113-122.

Wagrowski, D.M., Hites, R.A., 1997. Polycyclic aromatic hydrocarbon accumulation in urban, suburban, and rural vegetation. Environmental Science \& Technology 31, 279-282.

Wang, J., Bi, Y., Pfister, G., Henkelmann, B., Zhu, K., Schramm, K., 2009. Determination of PAH, PCB, and OCP in water from the Three Gorges Reservoir accumulated by semipermeable membrane devices (SPMD). Chemosphere 75, 1119-1127.

Wang, J.S., Busby Jr., W.F., 1993. Induction of lung and liver tumors by fluoranthene in a preweanling CD-1 mouse bioassay. Carcinogenesis 14, 1871-1874.

Wang, W., Simonich, S., Giri, B., Chang, Y., Zhang, Y., Jia, Y., Tao, S., Wang, R., Wang, B., Li, W., Cao, J., Lu, X., 2011. Atmospheric concentrations and air-soil gas exchange of polycyclic aromatic hydrocarbons (PAHs) in remote, rural village and urban areas of BeijingTianjin region, North China. Science of the Total Environment 409, 2942-2950.

Wang, Y.Q., Tao, S., Jiao, X.C., Coveney, R.M., Wu, S.P., Xing, B.S., 2008. Polycyclic aromatic hydrocarbons in leaf cuticles and inner tissues of six species of trees in urban Beijing. Environmental Pollution 151, 158-164.

Wang, H., Zhou, W., Wang, X., Gao, F., Zheng, H., Tong, L., Ouyang, Z., 2012. Ozone uptake by adult urban trees based on sap flow measurement. Environmental Pollution 162, 275-286.

Wuyts, K., Verheyen, K., De Schrijver, A., Cornelis, W. M., Gabriels, D., 2008. The impact of forest edge structure on longitudinal patterns of deposition, wind speed, and turbulence.

Atmospheric Environment 42, 8651-8660. 
Yin, S., Shen, Z., Zhou, P., Zou, X., Che, S., Wang, W., 2011. Quantifying air pollution attenuation within urban parks: An experimental approach in Shanghai, China. Environmental Pollution 159, 2155-2163.

Yli-Pelkonen, V., Scott, A.A., Viippola, V., Setälä, H., 2017a. Trees in urban parks and forests reduce $\mathrm{O}_{3}$, but not $\mathrm{NO}_{2}$ concentrations in Baltimore, MD, USA. Atmospheric Environment 167, 73-80.

Yli-Pelkonen, V., Setälä, H., Viippola. V., 2017b. Urban forests near roads do not reduce gaseous air pollutant concentrations but have an impact on particles levels. Landscape and Urban Planning 158, 39-47.

Yli-Pelkonen, V., Viippola, V., Kotze, D.J., Setälä, H., 2017c. Greenbelts do not reduce $\mathrm{NO}_{2}$ concentrations in near-road environments. Urban Climate 21, 306-317. 